\title{
Flash flood susceptibility modelling using geomorphometric approach in the Ushairy Basin, eastern Hindu Kush
}

\author{
Shakeel Mahmood ${ }^{1, *}$ (] and Atta-Ur Rahman ${ }^{2}$ \\ ${ }^{1}$ Department of Geography, Government College University Lahore, Lahore, Pakistan. \\ ${ }^{2}$ Department of Geography, University of Peshawar, Peshawar, Pakistan. \\ *Corresponding author. e-mail: shakeelmahmoodkhan@gmail.com
}

MS received 18 May 2018; revised 6 August 2018; accepted 20 August 2018; published online 2 April 2019

This study focuses on flash flood susceptibility modelling using geomorphometric ranking approach in the Ushairy Basin. In the study area, flash floods are highly unpredictable and the worst hydrometeorological disaster. An advanced spaceborne thermal emission and reflection radiometer global digital elevation model was used as input data in a geographic information system environment to delineate the target basin. A total of 17 sub-basins were delimited using a threshold of $4 \mathrm{~km}^{2}$. The attribute information of each sub-basin was analysed to compute the geomorphometric parameters by applying Hortonian and Strahler geomorphological models. The results were analysed and categorised into five classes using statistical techniques, and the rank score was assigned to each class of all parameters depending on their relation with flash flood risk. In this study, 16 parameters were analysed to quantify the geomorphometric number of each sub-basin depicting the degree of flash flood susceptibility. The geomorphometric number of each sub-basin was linked to the geo-database for spatial visualisation. The analysis reveals that extremely high, very high, high and moderate sub-basins susceptible to flash floods were spread over an area of $55 \%, 8.5 \%, 23.7 \%$, and $11.5 \%$, respectively. It was found that out of total settlements, $53 \%$ are located in the extremely highly and very highly susceptible sub-basins. In the study area, the upper reaches are characterised by snow-covered peaks, steep slopes and high drainage densities $\left(>1.7 \mathrm{~km} / \mathrm{km}^{2}\right)$. The analysis further indicated that the flash flood susceptibility increases with the increase in area, relief and relief ratio of the sub-basins. Model accuracy was assessed using primary data regarding past flood damages and human fatalities. Similarly, socio-demographic conditions of each sub-basin were also compared and linked to the extent of flash flood susceptibility. This study may assist the district government and district disaster management authority of Dir upper to initiate flood risk reduction strategies in highly susceptible zones of the Ushairy Basin.

Keywords. Susceptibility; modelling; flash floods; damages; GIS; Hindu Kush.

\section{Introduction}

Every year disasters are becoming more frequent and destructive with heavy material losses and thousands of fatalities around the globe (Gaume et al. 2009; Youssef et al. 2016). It is estimated that geophysical and hydro-meteorological disasters have been causing widespread damages to people and infrastructure (Collier 2007; Krausmann and Mushtaq 2008). Flood is one of the most devastating hydro-meteorological disasters (Rahman and Khan 2011, 2013; Rahman and Shaw 
2015; Mahmood et al. 2016a,b; Dawood et al. 2017). Worldwide, more than one-third of the land surface is exposed to floods, where over $70 \%$ of the population reside (Aksoy et al. 2016). It has been calculated that flooding events are increasing mainly due to the increasing intensity of rainfall, changes in land-use pattern and excessive melting of snow and glaciers (Kundzewicz and Jania 2007). It is evident that with increasing extreme precipitation events, the devastating floods might become more prevalent in future (Mazzorana et al. 2009; IPCC 2014). The multifaceted interaction of geomorphometric and hydro-climatic parameters with the landscapes and morphological structures of the watershed generates disastrous flash floods (Korytny and Kichigina 2006; Creutin et al. 2013). This has increased the potential for flash flood causalities and related damages (Mahmood et al. 2016a). Similarly, changes in land-use land cover, increased exposure and susceptibility may further intensify flash floods (Cantet et al. 2011).

Flash flood is one of the complex hydro-meteorological disasters claiming a high number of lives and causing severe economic losses (Jonkman and Vrijling 2008) because of the devastating rapid flood flow that usually occurs in a short period without adequate forecasting or warning (Ibarra 2012). Heavy to intense rainfall generates flash floods resulting in high levels of discharge (Creutin et al. 2013). Flash flood is a localised phenomenon that occurs in basins of few hundred square kilometres or less, with response times of a few hours or less (Creutin and Borga 2003). The rapid to extreme response of some basins to rainfall is because of their high drainage density, steep slopes and impermeable surfaces (Creutin and Borga 2003). Similarly, barren and impervious surfaces also increase surface run-off and sharply reduce the lag time for genesis of flash floods (Borga et al. 2007). This results in high peak discharge, often jeopardising human lives and settlements (DeGaetano 2009).

Generally, flash flood-generating factors include intense rainfall, gradient of the watershed, landuse and land cover, soil permeability and physical vulnerability to flood occurrences (Llasat et al. 2010; Shehata and Mizunaga 2018). Flash flood events are convective in nature. During the warm season, deep and moist convection results into torrential rainfall with extremely high intensity than any other rain-producing weather system and as a result generates flash floods (Kim et al. 2011). The barren and impervious surfaces increase surface run-off and sharply reduce the lag time for flash flood genesis (Mahmood et al. 2016b). Hu (2016) also reported that geomorphometric characteristics of the basin and prevailing meteorological conditions are responsible for the genesis of flash floods.

A number of quantitative and qualitative approaches exist in scientific literature for flash flood modelling within a watershed. A geomorphometric analysis is the quantitative technique for the evaluation of sub-basin characteristics (Horton 1945). Basin characteristics play a vital role in quantifying and analysing geomorphometric parameters to predict floods, sediment yields and erosion rates (Gardiner 1990). Currently, watershed delineation and geomorphometric parameter computation can be achieved by analysing remotely sensed data in a geographic information system (GIS) environment (Singh et al. 2013), under the established geomorphological models (Horton 1945; Miller 1953; Schumm 1956; Strahler 1957; Gardiner 1990). Many studies were carried out to assess the severity of risk at places susceptible to flash floods. In this regard, El-Shamy (1992) established the relationship between bifurcation ratio, drainage density and drainage frequency. Youssef et al. (2011) developed a GIS-based morphometric analysis approach to estimate the levels of flash flood risk for sub-basins. Elmoustafa and Mohamed (2013) used a weighted normalised risk factor for the risk assessment of floods. Elmaghraby et al. (2014) employed a morphometric analysis to evaluate the flash flood hazard of Al-Hamd sub-basins, western Saudi Arabia, using nine morphometric parameters, namely, watershed area, drainage density, stream frequency, shape index, slope index, relief ratio, ruggedness number, texture ratio and weighted mean bifurcation ratio, which have a direct influence on flash flooding. Farhan and Anaba (2016) used a GIS-based morphometric ranking approach for flash flood risk estimation. Singh and Singh (2017) utilised eight morphometric parameters for geomorphological analysis and watershed prioritisation. Mahmood and Rahman (2019) has modeled flash flood susceptibility using the integrated approach of geomorphometric and hydrological parameters.

The overall aim of this paper is to model and geo-visualise the susceptibility conditions of all sub-basins to flash floods. Susceptibility is the likelihood of a disastrous event occurring in an area supported by the overall topography of the region (Santangelo et al. 2011). Generally, it is 


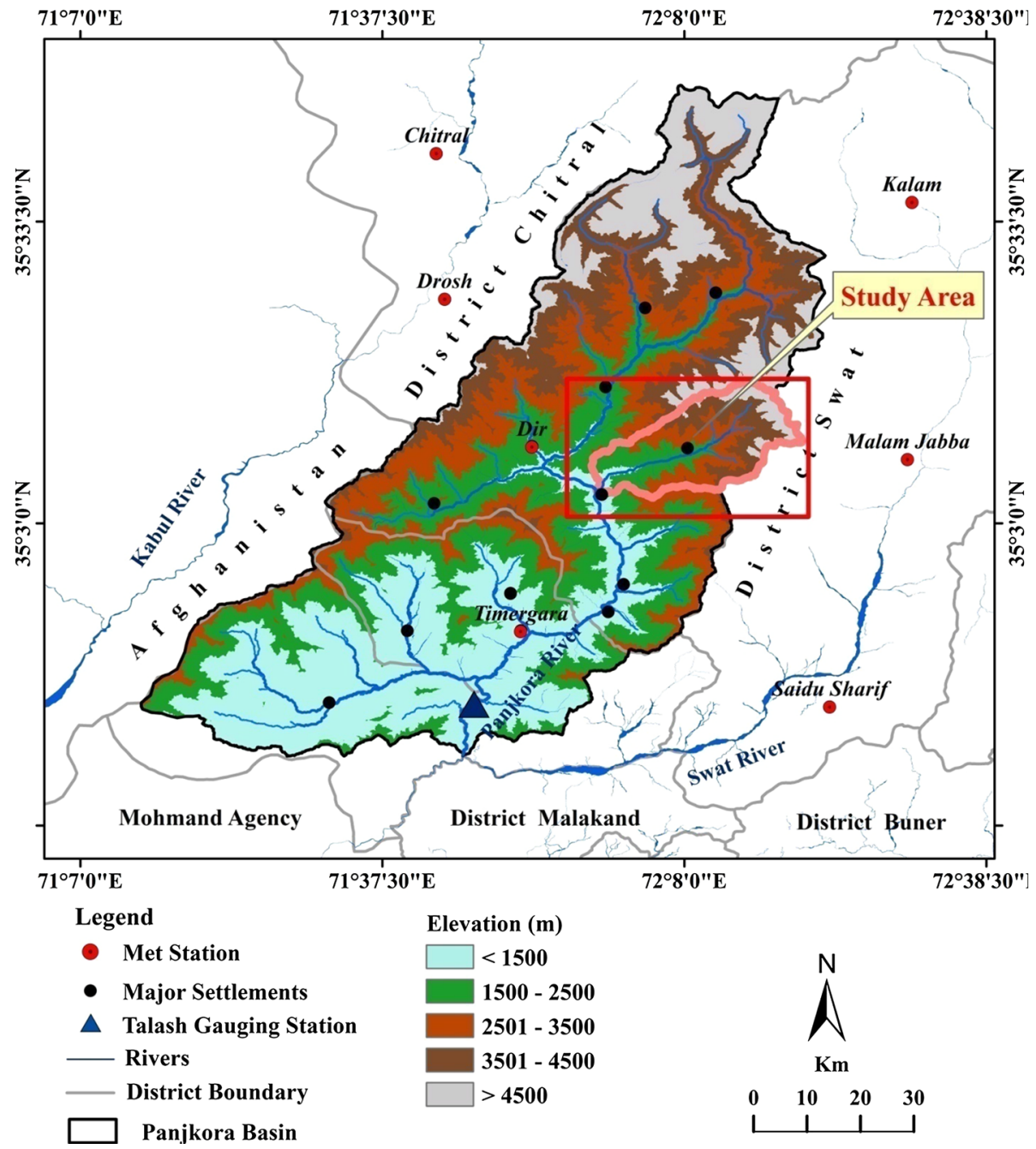

Figure 1. Location of the study area modified after ASTER GDEM 2011. Source: GoP (2010).

the degree to which an area can be affected by future extreme events. It is also an estimation of where the future events may occur without considering the temporal probability of an event (Tehrany et al. 2014; Dottori et al. 2016; Khosravi et al. 2016). This approach is useful for areas where it is difficult to obtain enough information concerning the temporal probability and occurrence of an event. The objectives of this study are to analyse the geomorphometric characteristics of each sub-basin and employ geomorphometric ranking approach to estimate the degree of flash flood susceptibility in the Ushairy Basin located in Eastern Hindu Kush. The results of this study will definitely be helpful for researchers, disaster managers and planners to deal with the susceptible areas and prioritise location-specific flood mitigation strategies for minimising the potential impacts of future flood events.

\section{Study area}

Geographically, the Ushairy Basin extends from $72^{\circ} 16^{\prime}-72^{\circ} 50^{\prime} \mathrm{E}$ longitude to $35^{\circ} 6^{\prime}-35^{\circ} 16^{\prime} \mathrm{N}$ latitude (figure 1). Physically, the study area is dominated by mountains showing variation in altitude that approximately ranges from 1000 to $4000 \mathrm{~m}$ asl. The lowest point is at Darora, while the highest point of the area is at Saidgai. Flash floods and soil erosion are common due to steep slopes and heavy degradation of vegetation (Rahman and Shaw 2015). The field survey reveals that disastrous flash floods have occurred four times recently (2005, 2010, 2014 and 2016) with devastating physical damages and human casualties (Mahmood et al. 2016a, b). Therefore, for this study, 2005 is selected as the base year. The total area of the basin is $391 \mathrm{~km}^{2}$, of which, forest cover is $294 \mathrm{~km}^{2}$, agricultural land is $29 \mathrm{~km}^{2}$, vacant land is $34 \mathrm{~km}^{2}$ and the remaining 
is built-up area (Muhammad 2011). The study area receives maximum precipitation in the form of snow during the winter. Generally, in the upper reaches, snowfall starts in November and descends downwards as the temperature falls in December. The melting of snow starts in March and goes on depending upon the elevation (Government of Pakistan (GoP) 2000). In an ice-cap zone, crops cannot grow; however, a few frost-resistant tree species grow along its lower part on steep slopes, shedding their cover for 1 or 2 months during the summer.

In the study area, the soil texture varies from loamy, sandy loamy to clayey in nature. In the upper areas, soil is exposed and susceptible to erosion due to steep and fragile slopes. Deep and rich soils occur on moderate slopes, and such areas are mostly terraced and used for cultivation purposes. Maize, wheat, potato and onion are the main crops grown in the region (Muhammad 2011). The total population of the Ushairy valley is 39,386 , of which 20,457 are male and 18,929 are female. Similarly, the average family size was 8.3 persons (GoP 2000).

\section{Methods and materials}

The methodology of this study comprises watershed modelling and susceptibility modelling. An advanced spaceborne thermal emission and reflection radiometer (ASTER) global digital elevation model (GDEM) is used as input data, downloaded from the open-source geo-database of the United States Geological Survey (USGS). GDEM has been produced as a joint activity of the Ministry of Economy, Trade, and Industry (METI) of Japan and the US National Aeronautics and Space Administration (NASA) and is available free of charge for everyone. The spatial extent of GDEM coverage is between $83^{\circ} \mathrm{N}$ and $83^{\circ} \mathrm{S}$ latitude with $30-\mathrm{m}$ spatial resolution. The estimated accuracies of GDEM for vertical and horizontal data are 20 and $30 \mathrm{~m}$, respectively, at a confidence level of $95 \%$. Even though this product is expected to be a better elevation data set for its spatial resolution and whole-world coverage (Zhao et al. 2010). The modelling course of action is explained stepwise in the following section.

In the first step, watershed modelling approach was implemented using GDEM as input data to model main basin and sub-basin boundaries and stream network (figure 2). The Ushairy Basin is further delineated into 17 sub-basins and extracted fifth-order stream network. For the smallest stream definition, sub-basins were delineated using a threshold area of $4 \mathrm{~km}^{2}$. The sub-basins are represented as Sb-1-Sb-17. The Strahler (1964) stream order technique is applied to define stream order. In the second step, 18 geomorphometric parameters of each sub-basin were quantified using established geomorphological models given in table 1 .

In the third step, a geo-morphometric ranking approach was employed by considering two groups of geomorphometric parameters to compute the geomorphometric number depicting the degree of flash flood susceptibility for each sub-basin after Farhan and Anaba (2016). Group I comprises 10 parameters, which are directly proportional to the degree of susceptibility: sub-basin area, circularity ratio, sub-basin relief, relief ratio, drainage density, stream frequency, stream order, total stream number, total stream length and subbasin gradient. Group II comprises seven parameters, which are inversely proportional to the degree of susceptibility: hypsonetric integral, elongation ratio, shape factor, compactness coefficient, ruggedness number, geometry number and length of overland flow (table 2).

The standardised geomorphometric ranking score of all parameters was quantified by applying mathematical equations (1) and (2) of each subbasin after Youssef et al. (2009), Pradhan (2010), and Farhan and Anaba (2016). The standardised geomorphometric ranking score of group I and group II parameters is calculated using equations (1) and (2), respectively:

$$
\begin{aligned}
& \text { Ranking score }=4\left(\frac{X^{\prime}-X_{\min }}{X_{\max }-X_{\min }}\right)+1, \\
& \text { Ranking score }=4\left(\frac{X^{\prime}-X_{\max }}{X_{\min }-X_{\max }}\right)+1,
\end{aligned}
$$

where $X^{\prime}$ is the parameter value of the selected basin, $X \min$ and $X \max$ are the minimum and maximum values of the same parameter among all basins, respectively. The rank score for each parameter regarding all sub-basins was defined as ranging from 1 to 5 depending upon the relation of parameter to the degree of susceptibility (table 2). Then geomorphometric number for each sub-basin was 


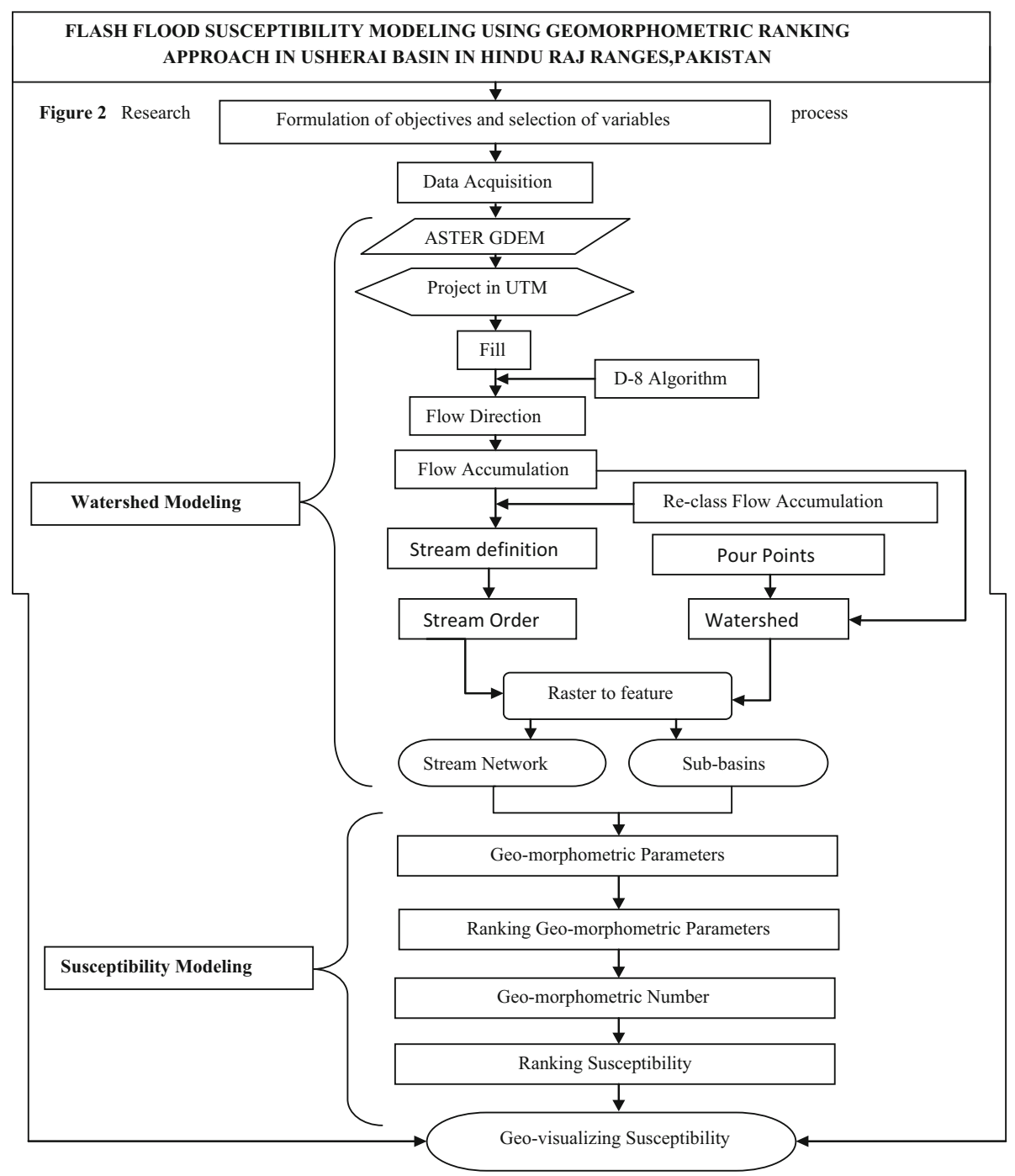

Figure 2. Research process.

determined by adding the standardised rank score of all parameters.

In the fourth step, geomorphometric numbers were categorised into five classes and named as extremely highly susceptible $(>56)$, very highly susceptible (53-56), highly susceptible (49-52), moderate susceptible (45-48) and low susceptible $(<45)$. In the last step, geomorphometric numbers of each sub-basin were linked to the geo-database in the ArcGIS10.2 environment, and the degree of flash flood susceptibility was geo-visualised in the form of susceptibility map. The model accuracy was assessed on the basis of primary data regarding the past flood damages, its economic loss in million Pakistani rupees (mPKR) and causalities. Similarly, the socio-demographic data of each subbasin were also compared and then linked to the susceptibility.

\section{Results and discussion}

The Ushairy Basin is drained by the left bank tributary 'River Ushairy' of Panjkora River System located in Eastern Hindu Kush Mountains. The Ushairy Basin has 17 sub-basins of different geomorphometric characteristics. The sub-basins located in the upper reach have snow-covered peaks and accumulate snow in narrow valleys. It receives intense rainfall particularly from thunder storms in the pre- and post-monsoon seasons (Mahmood et al. 2016a). The rainfall also increases the melting of snow, so the combined effect of rainwater and meltwater generates flash floods without prior warning with disastrous consequences. The lowest rainfall was recorded in 1971 and 2001, while the highest in 1979, 1986 and then in 2010 . 


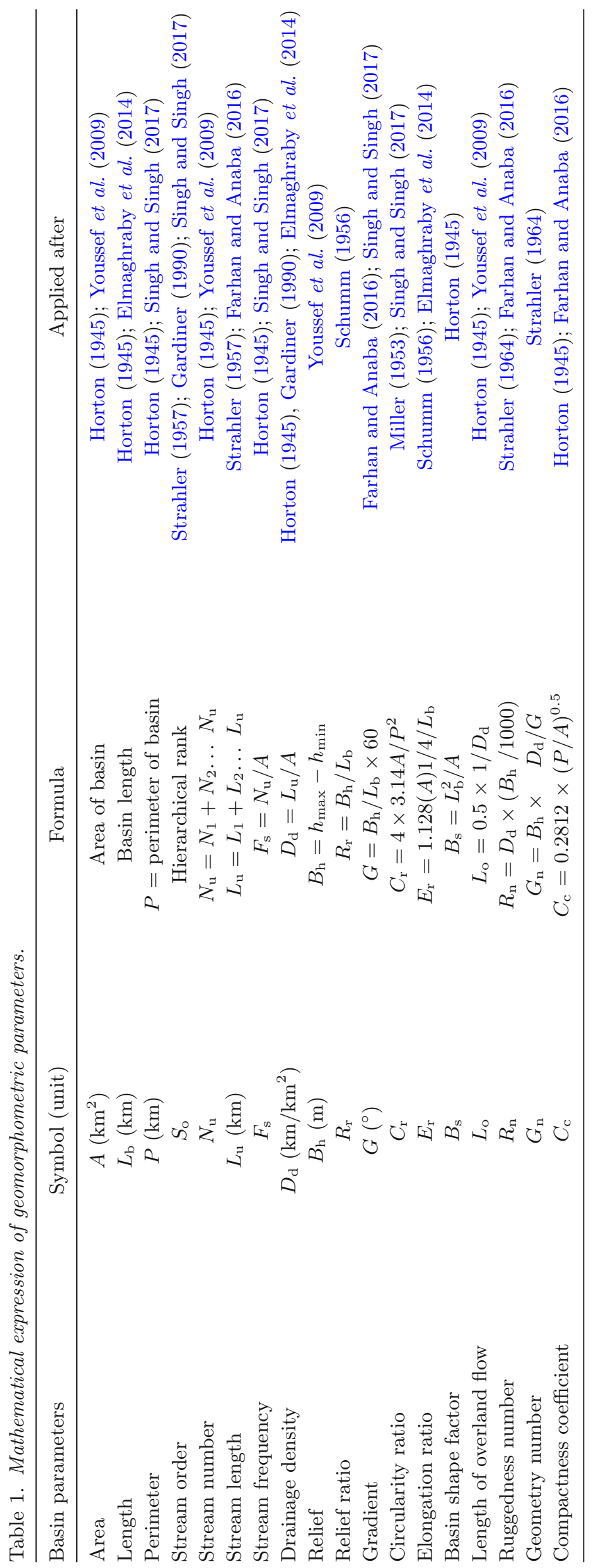


Table 2. Rank classes and rank score of geomorphometric parameters.

\begin{tabular}{|c|c|c|c|c|c|c|c|c|c|c|c|}
\hline $\begin{array}{c}\text { Geo- } \\
\text { morphometric } \\
\text { Parameters }\end{array}$ & $\begin{array}{l}\text { Ranked } \\
\text { Classes }\end{array}$ & $\begin{array}{l}\text { Rank } \\
\text { Score }\end{array}$ & $\begin{array}{c}\text { Geo- } \\
\text { morphometric } \\
\text { Parameters }\end{array}$ & $\begin{array}{l}\text { Ranked } \\
\text { Classes }\end{array}$ & $\begin{array}{l}\text { Rank } \\
\text { Score }\end{array}$ & $\begin{array}{c}\text { Geo- } \\
\text { morphometric } \\
\text { Parameters }\end{array}$ & $\begin{array}{l}\text { Ranked } \\
\text { Classes }\end{array}$ & $\begin{array}{l}\text { Rank } \\
\text { Score }\end{array}$ & $\begin{array}{c}\text { Geo- } \\
\text { morphometric } \\
\text { Parameters }\end{array}$ & $\begin{array}{l}\text { Ranked } \\
\text { Classes }\end{array}$ & $\begin{array}{l}\text { Rank } \\
\text { Score }\end{array}$ \\
\hline \multirow[b]{5}{*}{$\mathrm{B}_{\mathrm{h}}$} & $<500$ & 1 & \multirow[b]{5}{*}{ G } & $<10$ & 1 & \multirow[b]{5}{*}{$\mathrm{L}_{\mathrm{u}}$} & $<15$ & 1 & \multirow[b]{5}{*}{$\mathrm{L}_{\mathrm{o}}$} & $<.70$ & 5 \\
\hline & $\begin{array}{l}500- \\
1000\end{array}$ & 2 & & 15 -Oct & 2 & & $15-30$ & 2 & & $\begin{array}{c}0.70- \\
0.80\end{array}$ & 4 \\
\hline & $\begin{array}{l}1001- \\
1500\end{array}$ & 3 & & $15.1-20$ & 3 & & $30.1-45$ & 3 & & $\begin{array}{l}0.81- \\
0.90\end{array}$ & 3 \\
\hline & $\begin{array}{l}1501- \\
2000\end{array}$ & 4 & & $20.1-25$ & 4 & & $45.1-60$ & 4 & & $\begin{array}{c}0.911- \\
1.0\end{array}$ & 2 \\
\hline & $>2000$ & 5 & & $>25$ & 5 & & $>60$ & 5 & & $>1.0$ & 1 \\
\hline \multirow[b]{5}{*}{$\mathrm{R}$} & $<0.1$ & 1 & \multirow[b]{5}{*}{ A } & $<15$ & 1 & \multirow[b]{5}{*}{$\mathrm{F}_{\mathrm{s}}$} & $<3$ & 1 & \multirow[b]{5}{*}{$\mathrm{R}_{\mathrm{n}}$} & $<1.0$ & 5 \\
\hline & $0.11-0.2$ & 2 & & $15-30$ & 2 & & 4-Mar & 2 & & $1.0-2$ & 4 \\
\hline & $\begin{array}{l}0.21- \\
0.30\end{array}$ & 3 & & $30.1-45$ & 3 & & $4.1-5$ & 3 & & $2.1-3.0$ & 3 \\
\hline & $\begin{array}{c}0.31- \\
0.40\end{array}$ & 4 & & $45.1-60$ & 4 & & $5.1-6$ & 4 & & $3.1-4.0$ & 2 \\
\hline & $>0.40$ & 5 & & $>60$ & 5 & & $>6$ & 5 & & $>4.0$ & 1 \\
\hline \multirow[b]{5}{*}{$S_{0}$} & 1 & 1 & \multirow[b]{5}{*}{$\mathrm{E}_{\mathrm{r}}$} & $<0.3$ & 5 & \multirow[b]{5}{*}{$D_{d}$} & $<1.2$ & 1 & \multirow[b]{5}{*}{$\mathrm{G}_{\mathrm{n}}$} & $<200$ & 5 \\
\hline & 2 & 2 & & $0.3-0.5$ & 4 & & $1.2-1.4$ & 2 & & $200-225$ & 4 \\
\hline & 3 & 3 & & $0.51-0.7$ & 3 & & $1.41-1.6$ & 3 & & $\begin{array}{c}225.1- \\
250 \\
\end{array}$ & 3 \\
\hline & 4 & 4 & & $0.71-0.9$ & 2 & & $1.61-1.8$ & 4 & & $\begin{array}{c}250.1- \\
275\end{array}$ & 2 \\
\hline & 5 & 5 & & $>0.9$ & 1 & & $>1.8$ & 5 & & $>275$ & 1 \\
\hline \multirow[b]{5}{*}{$\mathrm{N}_{\mathrm{u}}$} & $<100$ & 1 & \multirow[b]{5}{*}{$B_{s}$} & $<0.2$ & 5 & \multirow[b]{5}{*}{$\mathrm{C}_{\mathrm{r}}$} & $<0.4$ & 1 & \multirow[b]{5}{*}{$\mathrm{C}_{\mathrm{c}}$} & $<1.0$ & 5 \\
\hline & $100-150$ & 2 & & $0.2-0.4$ & 4 & & $0.4-0.55$ & 2 & & $1.0-1.25$ & 4 \\
\hline & $151-200$ & 3 & & $0.41-0.6$ & 3 & & $\begin{array}{c}0.56- \\
0.70\end{array}$ & 3 & & $\begin{array}{c}1.251- \\
1.50\end{array}$ & 3 \\
\hline & $201-250$ & 4 & & $0.61-0.8$ & 2 & & $\begin{array}{c}0.71- \\
0.85\end{array}$ & 4 & & $\begin{array}{l}1.51- \\
1.75\end{array}$ & 2 \\
\hline & $>250$ & 5 & & $>0.8$ & 1 & & $>0.85$ & 5 & & $>1.75$ & 1 \\
\hline
\end{tabular}

Key: Increasing impact of geomorphometric parameters.

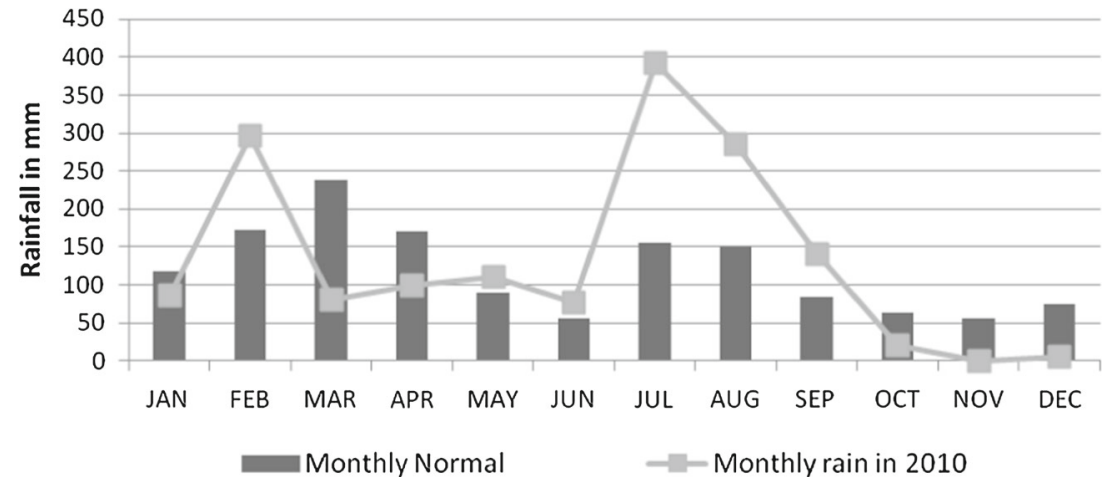

Figure 3. Mean monthly rainfall of past 50 years and 2010 extreme.

The analysis revealed that in the last four decades, there is a positive shift in rainfall, particularly in July. In the year 2010, an increase in the mean monthly rainfall had taken place from May to September. The normal for the months of May, June, July and August is 89, 56, 156 and $149 \mathrm{~mm}$, whereas the amount of rainfall in the year 2010 for the same months was 110, 76, 398 and $285 \mathrm{~mm}$, respectively (figure 3 ). The extreme event of 4-day wet spell (27-30th) with intensity of $99 \mathrm{~mm} /$ day occurred in July 2010. The highest intensity $(6.5 \mathrm{~mm} / \mathrm{h})$ was recorded on 29 July 2018 (Pakistan Meteorological Department $(\mathrm{PMD}))$. This wet spell became the flash floodgenerating factor in the entire valley, leading to flash floods that had never ever been experienced by this valley in the past. July and August are the hottest months with maximum temperature higher than $32^{\circ} \mathrm{C}$, causing melting of snow and glaciers in the upper catchment areas. The main source of discharge in the river is meltwater. The high-intensity rain accelerates melting. Thus, the meltwater has contributed in the genesis of high discharge which was beyond the capacity of the channel and generated massive flash floods with disastrous effects on human life, property and infrastructure (Mahmood et al. 2016b).

The geomorphometric characteristics of the subbasins greatly influence the peak discharge in the river responsible for the genesis of flash floods. 
Each year, these events cause human causalities and huge economic loss. In the past two decades, the extreme rainfall events in the study region have been increasing, similar to the global scenario (Dawood et al. 2017).

In short, the study area is susceptible to flash floods of different magnitudes as a result of increasing precipitation events and torrential rainfall. The hydro-geomorphology of the basin and anthropogenic activities, particularly forest cutting, have further increased the susceptibility to flash floods. A methodology for flash flood susceptibility modelling has been employed to understand its nature and spatial extent in the Ushairy Basin. The spatial distribution of flash flood potential is analysed. Then, the degree of flash susceptibility characterising each sub-basin is determined using the geomorphometric ranking approach by utilising 18 geomorphometric parameters of 17 sub-basins. The ranking score for the selected parameters was determined and then the geomorphometric number for each sub-basin was computed.

\subsection{Geomorphometric analysis}

The quantitative geomorphometric analysis was carried out to determine the linear, aerial and shape aspects of 17 sub-basins forming the study area. Results and analysis disclose that areawise, sub-basin Sb-16 is the smallest one covering an area of $4.2 \mathrm{~km}^{2}$ and sub-basin Sb-13 is the largest one with land area of $76.27 \mathrm{~km}^{2}$. Geomorphologically, the basin presents a dendritic type of drainage pattern. In this study, drainage density values range from 0.46 to $1.84 \mathrm{~km} / \mathrm{km}^{2}$. More than $80 \%$ of the sub-basins have drainage density more than $1.5 \mathrm{~km} / \mathrm{km}^{2}$. The drainage density is an important geomorphometric parameter in susceptibility modelling because it directly affects the flood hydrograph. The relief of sub-basins was high with maximum and minimum values of 2573 and $873 \mathrm{~m}$, respectively. A value of 15.3 for stream frequency indicates an impermeable sub-surface. The length of overland flow is one of the most important geomorphometric parameters affecting the hydrological and physiographical development of a drainage basin. It is approximately equal to half of the reciprocal of drainage density. In all sub-basins, the maximum and minimum values of length of overland flow were 1.07 and 0.33 , respectively. The values of basin's shape factor were less than unit for all sub-basins which depicts high flood discharge. The maximum and minimum values were 0.83 and 0.14 , respectively. The circularity ratio $\left(C_{\mathrm{r}}\right)$ indicates that sub-basins Sb11, Sb-14 and Sb-15 are more circular in shape having values of $0.627,0.617$ and 0.622 , respectively, while Sb-13 is elongated with $C_{\mathrm{r}}$ of 0.08 (table 3).

\subsection{Flash flood susceptibility}

The degree of flash flood susceptibility is determined by implementing the geomorphometric ranking approach for 17 sub-basins. The approach was executed to aggregate ranking score for different geomorphometric characteristics. The aggregated ranking score represents the geomorphometric number which has delineated the study area into five susceptibility zones. The greater the geomorphometric number, the higher is the sub-basin's susceptibility to flash floods and vice versa.

The analysis reveals that the geomorphometric number for all sub-basins ranges from 43 to 59 . Out of 17 sub-basins in the study area, Sb-1, Sb-2, Sb-12 and Sb-15 have the highest geomorphometric numbers (57-59) and thus highlighting the extremely highly susceptible zone to flash flooding covering a maximum land area of $45.5 \%\left(178 \mathrm{~km}^{2}\right)$ in the Ushairy Basin (table 4). The geomorphometric number of Sb-15 is 59. The Sb-14 covering 7\% $\left(27.6 \mathrm{~km}^{2}\right)$ of the total $\left(391 \mathrm{~km}^{2}\right)$ with geomorphometric number ranging from 53 to 56 is categorised as very highly susceptible zone, whereas the highly susceptible sub-basins are Sb-3, Sb-4, Sb-5, Sb6, Sb-9 and Sb-11 covering a land area of $19.6 \%$ $\left(77 \mathrm{~km}^{2}\right)$ with geomorphometric numbers ranging from 49 to 52 . The moderately susceptible sub-basins are Sb-7, Sb-8, Sb-10 and Sb-17, covering the land area of $9.3 \%\left(36.5 \mathrm{~km}^{2}\right)$ having geomorphometric numbers ranging from 45 to 48 and Sb-13 and Sb-15 have low susceptibility to floods with geomorphometric number less than 45 (figure 4). So, only $19.6 \%$ of the study area has low susceptibility to floods.

The extremely highly and very highly susceptible sub-basins have the highest ranking score for parameters of group I and lower ranking score for parameters of group II. For instance, maximum ranking score was obtained for sub-basin area, relief, stream frequency, drainage density, circularity ratio and gradient (table 4), whereas lower scores were obtained for geometry number and ruggedness number. This nature of geomorphometric characteristics of the sub-basins increases susceptibility flash floods and forms extremely high 
Table 3. Geomorphometric characteristics of the Ushairy Basin.

\begin{tabular}{|c|c|c|c|c|c|c|c|c|c|c|c|c|c|c|c|c|c|}
\hline \multirow{2}{*}{$\begin{array}{l}\text { Geo-morphometric } \\
\text { Parameters }\end{array}$} & \multicolumn{17}{|c|}{ Sub-basins } \\
\hline & Sb-1 & Sb-2 & Sb-3 & Sb-4 & Sb-5 & Sb-6 & Sb-7 & Sb-8 & Sb-9 & $\begin{array}{c}\text { Sb- } \\
10\end{array}$ & $\begin{array}{c}\text { Sb- } \\
11\end{array}$ & $\begin{array}{c}\text { Sb- } \\
12\end{array}$ & $\begin{array}{c}\text { Sb- } \\
13\end{array}$ & $\begin{array}{c}\text { Sb- } \\
14\end{array}$ & $\begin{array}{c}\text { Sb- } \\
15\end{array}$ & Sb-16 & Sb-17 \\
\hline $\mathbf{A}$ & 46.12 & 37.7 & $\begin{array}{c}26.1 \\
3\end{array}$ & 12.2 & 6.92 & 11.8 & 11.8 & 6.6 & 9.46 & 13.45 & 10.41 & 55.69 & 67.47 & 27.6 & 38.54 & 4.2 & 4.6 \\
\hline $\mathbf{B}_{\mathrm{h}}$ & 2252 & 2397 & 2573 & 2086 & 1894 & 1790 & 1236 & 1311 & 1593 & 1514 & 1583 & 1913 & 2209 & 2033 & 2180 & 873 & 1212 \\
\hline $\mathbf{R}_{\mathrm{r}}$ & 0.234 & $\begin{array}{c}0.24 \\
7\end{array}$ & $\begin{array}{c}0.45 \\
9\end{array}$ & $\begin{array}{c}0.30 \\
6\end{array}$ & $\begin{array}{c}0.33 \\
5\end{array}$ & $\begin{array}{c}0.31 \\
4\end{array}$ & $\begin{array}{c}0.21 \\
4\end{array}$ & $\begin{array}{c}0.30 \\
4\end{array}$ & $\begin{array}{c}0.30 \\
6\end{array}$ & 0.252 & 0.295 & 0.171 & 0.094 & 0.242 & 0.229 & $\begin{array}{c}0.349 \\
2\end{array}$ & $\begin{array}{c}0.346 \\
2\end{array}$ \\
\hline $\mathbf{S}_{\mathrm{o}}$ & 5 & 5 & 3 & 3 & 3 & 3 & 3 & 3 & 3 & 3 & 3 & 5 & 5 & 5 & 5 & 3 & 3 \\
\hline $\mathbf{N}_{\mathrm{u}}$ & 273 & 298 & 173 & 85 & 26 & 89 & 68 & 101 & 74 & 90 & 68 & 359 & 42 & 174 & 221 & 9 & 11 \\
\hline $\mathbf{L}_{\mathbf{u}}$ & $\begin{array}{c}78.51 \\
8\end{array}$ & $\begin{array}{c}60.3 \\
3\end{array}$ & $\begin{array}{c}43.3 \\
3\end{array}$ & $\begin{array}{c}19.8 \\
5\end{array}$ & $\begin{array}{c}10.9 \\
4\end{array}$ & $\begin{array}{c}20.7 \\
4\end{array}$ & $\begin{array}{c}21.7 \\
1\end{array}$ & $\begin{array}{c}12.0 \\
8\end{array}$ & 14.4 & 22.13 & 15.56 & 87.97 & 31.26 & 44.51 & 60.94 & 6.25 & 6.85 \\
\hline $\mathbf{F}_{\mathrm{s}}$ & 5.919 & $\begin{array}{c}7.90 \\
4\end{array}$ & 6.62 & $\begin{array}{c}6.96 \\
7\end{array}$ & $\begin{array}{c}3.75 \\
7\end{array}$ & $\begin{array}{c}7.54 \\
2\end{array}$ & $\begin{array}{c}5.76 \\
2\end{array}$ & 15.3 & $\begin{array}{c}7.82 \\
2\end{array}$ & 6.691 & 6.532 & 6.446 & 0.014 & 6.304 & 5.734 & 2 & 2.3 \\
\hline $\mathbf{D}_{\mathrm{d}}$ & 1.7 & 1.6 & 1.65 & 1.62 & 1.58 & 1.75 & 1.84 & 1.83 & 1.52 & 1.64 & 1.49 & 1.57 & 0.463 & 1.61 & 1.58 & 1.42 & 1.48 \\
\hline $\mathrm{C}_{\mathrm{r}}$ & 0.569 & $\begin{array}{c}0.54 \\
1\end{array}$ & $\begin{array}{c}0.49 \\
9\end{array}$ & 0.53 & $\begin{array}{c}0.45 \\
6\end{array}$ & $\begin{array}{c}0.59 \\
2\end{array}$ & 0.56 & $\begin{array}{c}0.51 \\
6\end{array}$ & $\begin{array}{c}0.59 \\
9\end{array}$ & 0.547 & 0.627 & 0.577 & 0.08 & 0.617 & 0.622 & 0.61 & 0.56 \\
\hline G & 23.3 & 26 & $\begin{array}{c}27.5 \\
6\end{array}$ & 18.4 & 20.1 & $\begin{array}{c}18.8 \\
4\end{array}$ & $\begin{array}{c}12.8 \\
5\end{array}$ & $\begin{array}{c}18.2 \\
9\end{array}$ & $\begin{array}{c}18.3 \\
8\end{array}$ & 15.14 & 17.72 & 20.3 & 11.68 & 25.1 & 23.76 & 20.95 & 20.7 \\
\hline $\mathbf{E}_{\mathbf{r}}$ & 0.798 & $\begin{array}{c}0.71 \\
4\end{array}$ & 0.8 & $\begin{array}{c}0.57 \\
9\end{array}$ & $\begin{array}{c}0.52 \\
5\end{array}$ & 0.68 & $\begin{array}{c}0.67 \\
1\end{array}$ & $\begin{array}{c}0.67 \\
4\end{array}$ & $\begin{array}{c}0.66 \\
7\end{array}$ & 0.689 & 0.679 & 0.756 & 0.397 & 0.75 & 0.154 & 0.92 & 0.69 \\
\hline $\mathbf{B}_{\mathrm{s}}$ & 0.5 & 0.4 & 0.83 & 0.26 & 0.21 & 0.36 & 0.35 & 0.35 & 0.34 & 0.37 & 0.36 & 0.44 & 0.14 & 0.39 & 0.42 & 0.58 & 0.66 \\
\hline $\mathbf{L}_{0}$ & 0.85 & 0.8 & $\begin{array}{c}0.82 \\
5\end{array}$ & 0.81 & 0.79 & $\begin{array}{c}0.87 \\
5\end{array}$ & 0.92 & $\begin{array}{c}0.91 \\
5\end{array}$ & 0.76 & 0.82 & 0.745 & 0.785 & 1.07 & 0.805 & 0.79 & 0.35 & 0.33 \\
\hline $\mathbf{R}_{\mathbf{n}}$ & $\begin{array}{c}3.828 \\
4\end{array}$ & $\begin{array}{c}3.83 \\
5\end{array}$ & $\begin{array}{c}4.24 \\
5\end{array}$ & $\begin{array}{c}3.37 \\
9\end{array}$ & $\begin{array}{c}2.99 \\
2\end{array}$ & $\begin{array}{c}3.13 \\
2\end{array}$ & $\begin{array}{c}2.27 \\
4\end{array}$ & $\begin{array}{c}2.39 \\
9\end{array}$ & $\begin{array}{c}2.42 \\
1\end{array}$ & 2.482 & 2.358 & 3.003 & 1.02 & 3.273 & 3.444 & 1.23 & 1.79 \\
\hline $\mathbf{G}_{\mathbf{n}}$ & 281.5 & 259 & 154 & $\begin{array}{c}183 . \\
6\end{array}$ & $\begin{array}{c}148 . \\
8\end{array}$ & $\begin{array}{c}166 . \\
2\end{array}$ & $\begin{array}{c}176 . \\
9\end{array}$ & $\begin{array}{c}131 . \\
2\end{array}$ & $\begin{array}{c}131 . \\
7\end{array}$ & 164 & 133 & 291.6 & 180 & 225.4 & 250.3 & 59 & 86 \\
\hline $\mathbf{C}_{\mathrm{c}}$ & 1.32 & 1.35 & 1.41 & 1.36 & 1.47 & 1.29 & 1.39 & 1.38 & 1.28 & 1.34 & 1.25 & 1.31 & 3.82 & 1.27 & 1.26 & 1.05 & 1.03 \\
\hline
\end{tabular}

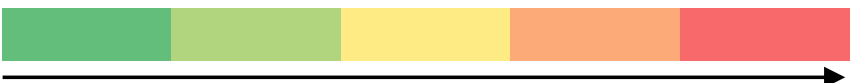

Key: Increasing impact of geomorphometric parameters.

and very high susceptibility zones in the study area. Similarly, low susceptible sub-basins have the lowest ranking score for parameters of group I and high values for parameters of group II. The ranking score of sub-basin area, relief and drainage density shows a lower value (1) having direct impact on flash flood genesis, whereas the length of overland flow and geometry number shows a maximum (5) because its impact on flash flood genesis is inverse. This geomorphometric character lowers the degree of flash flood susceptibility and forms low susceptibility zone of the study area.

The analysis further reveals that extremely highly susceptible sub-basins are spatially distributed in the upper reaches of the study area, whereas low and moderately susceptible sub-basins are located in the lower reaches of the study area. The sub-basins in the upper catchment covering more land area than others are located in the middle parts of the study area. These basins also have high drainage density, relief ratio and lower geometry number, elongation ratio and compactness coefficient. The basin's shape factor and relief have an influence on the flash flood genesis because they affect the time concentration in the main channel and the basin outflow point. Similarly, the topographic contrast produces important differences in sub-basins of upper reach and lower reach. The upper reach sub-basins are characterised by steep channel gradient and high drainage densities generating high surface run-off that results in flash floods.

The analysis also indicated that out of the total human settlements, $53 \%$ are located in the extremely highly and very highly susceptible subbasins, $30 \%$ are situated in highly susceptible zones, while remaining are distributed in low and moderately susceptible areas. The analysis indicated that most of the human population and their property are very highly susceptible to flash floods. This increases the risk of human causalities and socio-economic losses. The areas are susceptible because they are located in hilly regions with steep slopes and snow-covered peaks. Dawood et al. (2017) also found that the upper catchment areas in the eastern Hindu Kush region receive 
Table 4. Geomorphometric ranking score.

\begin{tabular}{|c|c|c|c|c|c|c|c|c|c|c|c|c|c|c|c|c|c|}
\hline \multirow{2}{*}{$\begin{array}{l}\text { Geo-morphometric } \\
\text { Parameters }\end{array}$} & \multicolumn{17}{|c|}{ Sub-basins } \\
\hline & Sb-1 & Sb-2 & Sb-3 & Sb-4 & Sb-5 & Sb-6 & Sb-7 & Sb-8 & Sb-9 & Sb-10 & Sb-11 & Sb-12 & Sb-13 & Sb-14 & Sb-15 & Sb-16 & Sb-17 \\
\hline $\mathbf{A}$ & 4 & 3 & 3 & 2 & 2 & 2 & 2 & 1 & 1 & 1 & 1 & 4 & 5 & 3 & 3 & 1 & 1 \\
\hline $\mathbf{B}_{\mathrm{h}}$ & 5 & 5 & 5 & 5 & 4 & 4 & 3 & 3 & 4 & 4 & 4 & 4 & 5 & 5 & 5 & 2 & 3 \\
\hline $\mathbf{R}_{\mathrm{r}}$ & 3 & 3 & 5 & 4 & 4 & 4 & 3 & 4 & 4 & 3 & 3 & 2 & 1 & 3 & 3 & 3 & 3 \\
\hline$S_{0}$ & 5 & 5 & 3 & 3 & 3 & 3 & 3 & 3 & 3 & 3 & 3 & 5 & 5 & 5 & 5 & 3 & 3 \\
\hline $\mathbf{N}_{\mathbf{u}}$ & 5 & 5 & 3 & 1 & 1 & 1 & 1 & 2 & 1 & 1 & 1 & 5 & 5 & 3 & 4 & 1 & 1 \\
\hline $\mathbf{L}_{\mathbf{u}}$ & 5 & 5 & 3 & 2 & 2 & 2 & 2 & 1 & 1 & 2 & 2 & 5 & 3 & 3 & 5 & 1 & 1 \\
\hline $\mathbf{F}_{\mathrm{s}}$ & 4 & 5 & 5 & 5 & 2 & 5 & 4 & 4 & 4 & 4 & 4 & 5 & 1 & 5 & 4 & 1 & 1 \\
\hline $\mathbf{D}_{\mathrm{d}}$ & 5 & 4 & 4 & 4 & 3 & 5 & 4 & 4 & 3 & 4 & 3 & 4 & 1 & 4 & 4 & 3 & 3 \\
\hline $\mathbf{C}_{\mathbf{r}}$ & 3 & 2 & 2 & 2 & 2 & 3 & 3 & 2 & 3 & 2 & 3 & 3 & 1 & 3 & 3 & 3 & 3 \\
\hline G & 4 & 5 & 5 & 3 & 4 & 3 & 3 & 3 & 3 & 3 & 3 & 4 & 2 & 5 & 4 & 4 & 4 \\
\hline $\mathbf{E}_{\mathbf{r}}$ & 2 & 2 & 2 & 3 & 3 & 3 & 3 & 3 & 3 & 3 & 3 & 2 & 2 & 2 & 5 & 1 & 3 \\
\hline $\mathbf{B}_{\mathrm{s}}$ & 3 & 4 & 1 & 4 & 4 & 4 & 4 & 4 & 4 & 4 & 4 & 3 & 5 & 4 & 3 & 3 & 2 \\
\hline $\mathbf{L}_{0}$ & 3 & 4 & 3 & 3 & 4 & 3 & 2 & 2 & 4 & 3 & 4 & 4 & 1 & 3 & 4 & 5 & 5 \\
\hline $\mathbf{R}_{\mathbf{n}}$ & 2 & 2 & 1 & 2 & 3 & 2 & 3 & 3 & 3 & 3 & 3 & 3 & 4 & 2 & 2 & 4 & 4 \\
\hline $\mathbf{G}_{\mathbf{n}}$ & 1 & 2 & 2 & 5 & 5 & 5 & 5 & 5 & 5 & 5 & 5 & 1 & 5 & 3 & 2 & 5 & 5 \\
\hline $\mathbf{C}_{\mathrm{e}}$ & 3 & 3 & 3 & 3 & 3 & 3 & 3 & 3 & 3 & 3 & 4 & 3 & 1 & 3 & 3 & 4 & 4 \\
\hline Total Score & 57 & 59 & 50 & 51 & 49 & 52 & 48 & 47 & 49 & 48 & 50 & 57 & 47 & 56 & 59 & 44 & 46 \\
\hline
\end{tabular}

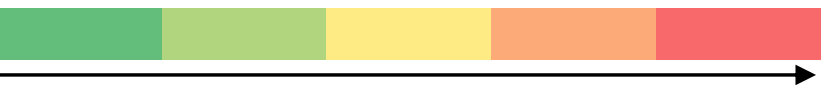

Key: Increasing impact of geomorphometric ranking score.

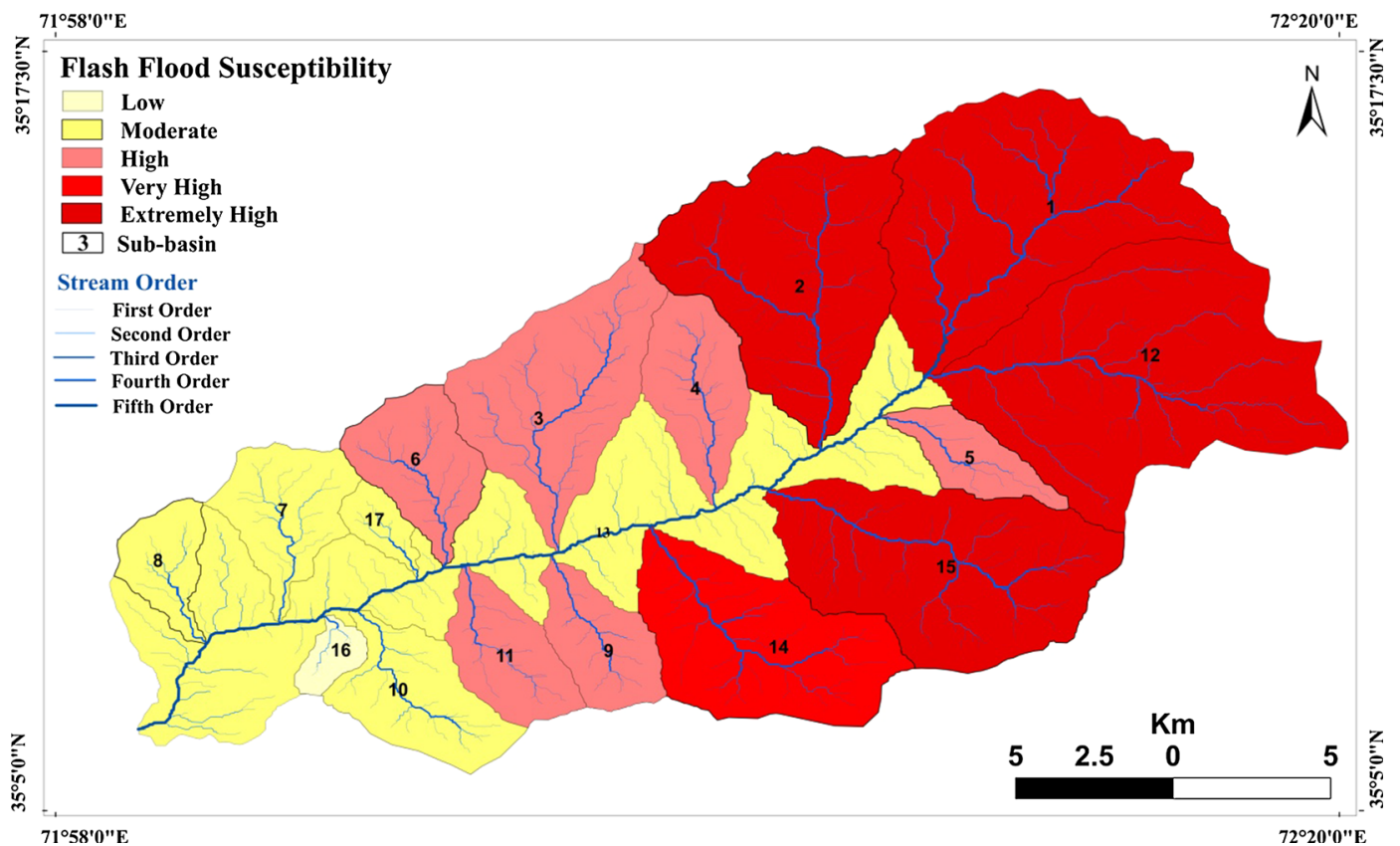

Figure 4. Geo-visualisation of sub-basin flash flood susceptibility by implementing the geo-morphometric ranking approach. 


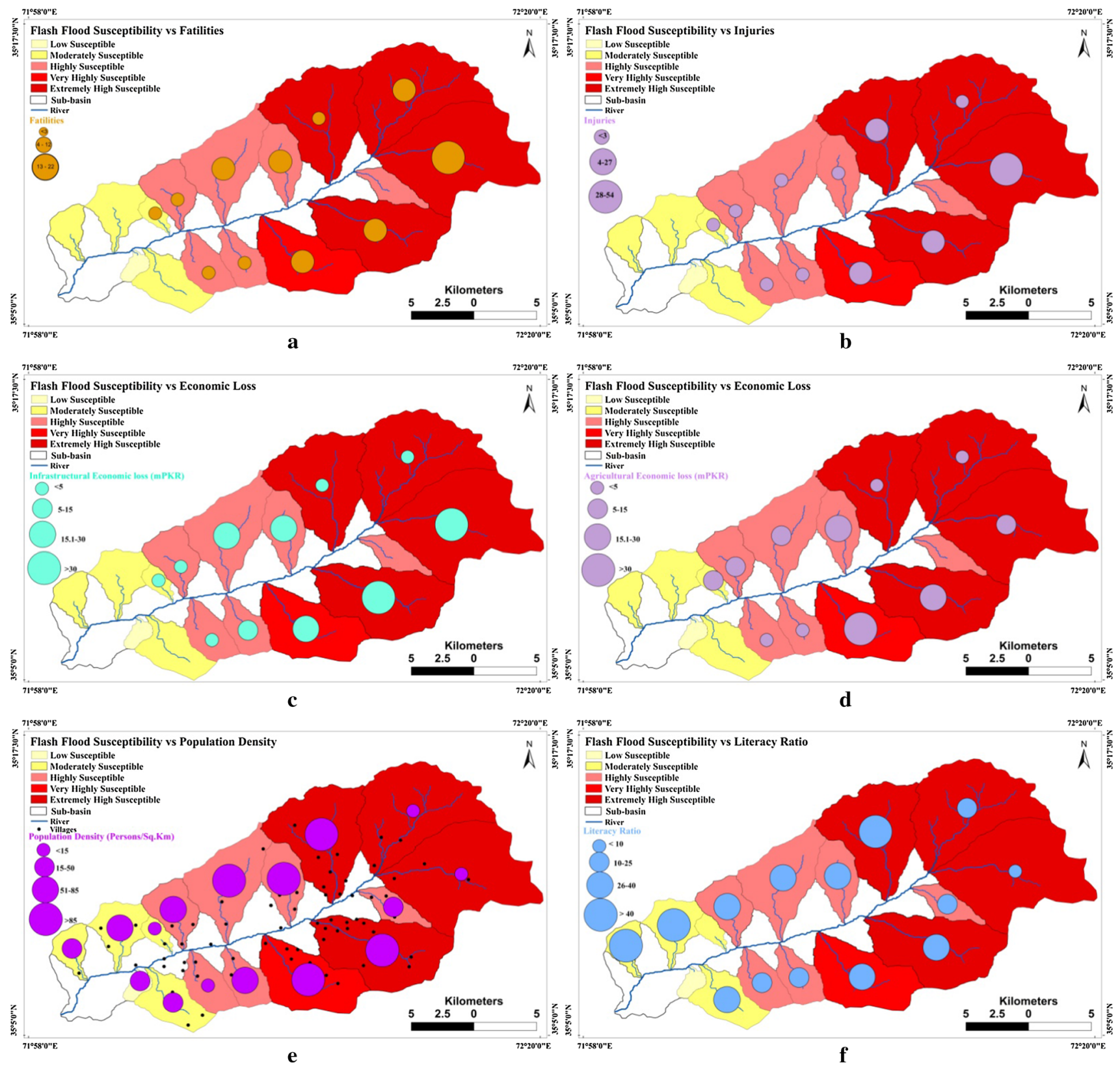

Figure 5. Flash flood susceptibility versus past floods: (a) fatalities, (b) injuries, (c) infrastructural economic losses in mPKR, (d) agricultural economic losses in $\mathrm{mPKR},(\mathbf{e})$ population density in persons $/ \mathrm{km}^{2}$ and (f) literacy ratio.

more rainfall due to orographic effects. Thus, the combined effect of meltwater and rainwater results in flash floods without any prior warning. The peak flow is further intensified by steep gradient and narrowness of the channels. Consequently, most of the villages are situated in the proximity of torrents, and streams are likely to get damaged by floods. Similarly, temporary settlements are also located in the proximity of contributing streams, particularly in the upper catchment of the study area. When flash floods come, they first interact with the temporary settlements and damage them.
In the disastrous flash flood events of 2005, 2010, 2014 and 2016, most of the injuries and fatalities (190) were reported from the extremely highly, very highly and highly susceptible areas. Similarly, these events have caused tens of millions of economic loss to infrastructure and agriculture. The houses and agriculture activities have been affected by flash floods since 2005. About $80 \%$ of the past human and economic losses have been occurred in the highly susceptible zone. It depicts that the highly susceptible zones have $80 \%$ model accuracy in the case of economic loss, 
while in terms of fatalities and injuries, the model accuracy is $100 \%$ (figure $5 \mathrm{a}-\mathrm{f}$ ). The literacy ratio is also somehow responsible in modulating the flash flood risk susceptibility because the high level of education reduces susceptibility by avoiding activities in highly exposed areas. Therefore, the literacy ratio and population density were also used to find the accuracy of the model results.

In short, flash flood susceptibility is an estimation of where the future events may occur and to which degree the area will be affected. In the wake of recent climate change, the magnitude and frequency of disastrous flash flood events will further grow, which is a serious threat for highland river systems where the Ushairy Basin is also located. Such conditions have made more than $50 \%$ land area, population and human settlements extremely to highly susceptible. The spatial visualisation of susceptibility presents a pattern that categorises the Ushairy Basin into upper, middle and lower zones. The upper zone has extreme to very high susceptibility, middle zone has high susceptibility and lower zone has moderate to low susceptibility. These zones also validate the results of the geomorphometric ranking approach because past flood damages also present the same spatial pattern.

\section{Conclusion}

This study concludes that a GIS-based geomorphometric analysis and satellite data can be employed to estimate flash flood susceptibility and spatial potential flood hazard was geo-visualised which shows flash flood-prone sub-basins across the study area. The mathematical computationbased generated maps/information will assist planners and decision-makers to understand the spatial distribution of flood hazard to formulate flood mitigation strategies to reduce the negative impacts of repetitive flooding on the residents and infrastructure. The implementation of GDEM in the GIS environment made it possible to delineate the subbasins at threshold of $4 \mathrm{~km}^{2}$, and a total of 17 sub-basins were delimited. The river network is of fifth order representing the dendritic drainage system. Then, the morphometric ranking approach is employed to categorise sub-basins into low, moderate and high flood, very high and extremely high susceptibility zones.

The analysis reveals that geomorphometric number is directly proportional to flood susceptibility. In the study area, the geomorphometric number for all sub-basins ranges from 43 to 59 . Out of 17 sub-basins, Sb-13 and Sb-16 have the lowest geomorphometric number $(<45)$ that highlights low susceptible areas. The moderately susceptible subbasins are Sb-7, Sb- 8 , Sb-10 and Sb-17 having geomorphometric numbers ranging from 45 to 48 . The highly susceptible sub-basins are Sb-3, Sb-4, Sb-5, Sb-6, Sb-9 and Sb-11 with geomorphometric numbers ranging from 49 to 52 . The Sb-14 is very highly susceptible with geomorphometric number 56 . The extremely highly susceptible sub-basins are Sb-1, Sb-2, Sb-12 and Sb-15 covering a maximum land area $(45.5 \%)$ with highest geomorphometric number $(>56)$ and thus highlighting the extremely highly susceptible areas to flash flooding. So, as the geomorphometric number increases, the susceptibility of the sub-basins increases. The model results were validated by integrated geo-visualisation of flash flood susceptibility and spatial distribution of past flood fatalities, injuries and economic losses.

The study further concludes that spatial visualisation of susceptibility presents a pattern that categorises the Ushairy Basin into upper, middle and lower zones. The upper zone has extreme to very high susceptibility, middle zone has high susceptibility and lower zone has moderate to low susceptibility. These zones also validate the results of the geomorphometric ranking approach because past flood damages also present the same spatial pattern.

This micro-level analysis provides foundation and guidelines for flood hazard management by the District Disaster Management Authorities. However, the National Disaster Management Authority may also replicate the same methodology over an extensive area of the country for getting productive results. This methodology may also be applied in regions of the world having similar characteristics to the Ushairy Basin. Our findings further indicated that these flood susceptibility maps can assist disaster planners, decision-making authorities and other flood dealing agencies to deal with the location-specific flood risk management and planning in the region. This study will be helpful for research work regarding hydrological hazards and disaster planners to oversee the highly susceptible areas by deploying location-specific flood mitigation strategies.

\section{Acknowledgements}

We would like to thank the anonymous reviewers for their precious suggestions and the District 
Disaster Management Authority for providing the concerned data. We would also like to thank and acknowledge the residents of the surveyed villages for providing the data.

\section{References}

Aksoy H, Kirca V S O, Burgan H I and Kellecioglu D 2016 Hydrological and hydraulic models for determination of flood-prone and flood inundation areas; Proc. Int. Ass. Hydrol. Sci. 373 137-141.

Borga M, Boscolo P, Zanon F and Sangati M 2007 Hydrometeorological analysis of the August 29, 2003 flash flood in the eastern Italian Alps; J. Hydrometeorol. 8(5) 1049 1067.

Cantet P, Bacro J and Arnaud P 2011 Using a rainfall stochastic generator to detect trends in extreme rainfall. Stoch. Environ. Res. Risk Assess. 25 429-441.

Collier C 2007 Flash flood forecasting: What are the limits of predictability?; Quart. J. Roy. Meteor. Soc. 133 3-23.

Creutin J D and Borga M 2003 Radar hydrology modifies the monitoring of flash-flood hazard; Hydrol. Process. 17(7) 1453-1456.

Creutin J D, Borga M, Gruntfest E, Lutoff C and Zoccatelli D 2013 A space and time framework for analyzing human anticipation of flash floods; J. Hydrol. 482 14-24.

Dawood M, Mahmood S, Rahman G and Rahman A 2017 Impact of rainfall fluctuation on river discharge In Hindu Kush region, Pakistan; Abasyn J. Soc. Sci. 10 246-259.

DeGaetano A T 2009 Time-dependent changes in extreme-precipitation return-period amounts in the continental United States; J. Appl. Meteorol. Clim. 48(10) 2086-2099.

Dottori F, Martina M L V and Figueiredo R 2016 A methodology for flood susceptibility and vulnerability analysis in complex flood scenarios; J. Flood Risk Manag., https:// doi.org/10.1111/jfr3.12234.

Elmaghraby M, Masoud M and Niyazi B 2014 Assessment of surface runoff in arid, data scarce regions: An approach applied to Wadi Al-Hamd, Al Madinah Al Munawarah, Saudi Arabia; Life Sci. J. 11 271-289.

Elmoustafa A M and Mohamed M M 2013 Flash flood risk assessment using morphological parameters in Sinai Peninsula; J. Mod. Hydrol. 3 122-129.

El-Shamy I 1992 Recent recharge and flash flooding opportunities in the Eastern Desert, Egypt; Ann. Geol. Sur. Egypt $18323-334$.

Farhan Y and Anaba O 2016 Flash flood risk estimation of WadiYutum (Southern Jordan) watershed using GIS based morphometric analysis and remote sensing techniques; J. Mod. Hydrol. 6(02) 79.

Gardiner V 1990 Drainage basin morphometry; In: Geomorphological techniques (ed.) Goudie A, Unwin Hyman, London, pp. 71-81.

Gaume E, Bain V, Bernardara P, Newinger O, Barbuc M and Bateman A 2009 A compilation of data on European flash floods; J. Hydrol. 367 70-78.

Government of Pakistan (GoP) 2000 District census report of Upper Dir. Population census organization, Islamabad.
Horton R E 1945 Erosional development of streams and their drainage basins: Hydrophysical approach to quantitative morphology; Geol. Soc. Am. Bull. 56(3) 275-370.

$\mathrm{Hu}$ H 2016 Rainstorm flash flood risk assessment using genetic programming: A case study of risk zoning in Beijing; Nat. Hazards 83(1) 485-500.

Ibarra E M 2012 A geographical approach to post-flood analysis: The extreme flood event of 12 October 2007 in Calpe (Spain); Appl. Geogr. 32 490-500.

IPCC 2014 Climate Change 2014: Synthesis Report; Contribution of Working Groups I, II and III to the Fifth Assessment Report of the Intergovernmental Panel on Climate Change (IPCC) Geneva, Switzerland, 151.

Jonkman S N and Vrijling J K 2008 Loss of life due to floods; J. Flood Risk Manag. 1 43-56.

Khosravi K, Nohani E, Maroufinia E and Pourghasemi H R 2016 A GIS-based flood susceptibility assessment and its mapping in Iran: A comparison between frequency ratio and weights-of-evidence bivariate statistical models with multi-criteria decision-making technique; Nat. Hazards 83(2) 947-987.

Kim J, Kuwahara Y and Kumar M 2011 A DEM-based evaluation of potential flood risk to enhance decision support system for safe evacuation; Nat. Hazards $\mathbf{5 9}$ 1561-1572.

Korytny L M and Kichigina N V 2006 Geographical analysis of river floods and their causes in southern East Siberia; Hydrol. Sci. J. 51(3) 450-464.

Krausmann E and Mushtaq F 2008 A qualitative Natech damage scale for the impact of floods on selected industrial facilities; Nat. Hazards 46 179-197.

Kundzewicz Z W and Jania J A 2007 Extreme hydro-meteorological events and their impacts. From the global down to the regional scale; Geo. Polonica. $\mathbf{8 0}(\mathbf{2})$ 9-23.

Llasat M C, Llasat-Botija M, Rodriguez A and Lindbergh S 2010 Flash floods in Catalonia: A recurrent situation; Adv. Geosci. 26 105-111.

Mahmood S, Khan A H and Mayo S M 2016a Exploring underlying causes and assessing damages of 2010 flash flood in the upper zone of Panjkora river; Nat. Hazards 83(2) 1213-1227.

Mahmood S, Khan A H and Ullah S 2016b Assessment of 2010 flash flood causes and associated damages in Dir Valley, Khyber Pakhtunkhwa Pakistan; Int. J. Disast. Risk RE 16 215-223.

Mahmood S and Rahman A 2019 Flash Flood Susceptibility Modelling using Geo-morphometric and Hydrological Approaches in Panjkora Basin, Eastern Hindu Kush, Pakistan; Environ. Earth Sci. 78(1) 43-58.

Mazzorana B, Hübl J and Fuchs S 2009 Improving risk assessment by defining consistent and reliable system scenarios; Nat. Hazard Earth Syst. 9(1) 145-159.

Miller V 1953 A quantitative geomorphic study of drainage basin characteristics in the Clinch Mountain Area, Virginia and Tennessee; Project NR 389-402, Technical Report 3, Department of Geology, ONR, Columbia University, New York.

Muhammad S K 2011 Diversity of vascular plants, ethnobotany and conservation status of Ushairy Valley, District Dir, Upper NWFP Northern Pakistan; Doctoral Dissertation, Quaid-i-Azam University, Islamabad. 
Pradhan B 2010 Flood susceptible mapping and risk area delineation using logistic regression, GIS and remote sensing; J. Spatial Hydrol. 9(2).

Rahman A and Khan A N 2011 Analysis of flood causes and associated socio-economic damages in The Hindu Kush region; Nat. Hazards $\mathbf{5 9 ( 3 )} 1239$.

Rahman A and Khan A N 2013 Analysis of 2010-flood causes, nature and magnitude in the Khyber Pakhtunkhwa, Pakistan; Nat. Hazards 66(2) 887-904.

Rahman A and Shaw R (eds) 2015 Floods in The Hindu Kush region: Causes and socio-economic aspects; In: Mountain hazards and disaster risk reduction, Springer, Tokyo, pp. 33-52.

Santangelo N, Santo A, Di Crescenzo G, Foscari G, Liuzza V, Sciarrotta S and Scorpio V 2011 Flood susceptibility assessment in a highly urbanized alluvial fan: The case study of Sala Consilina (southern Italy); Nat. Hazard Earth Syst. 11(10) 2765.

Schumm S A 1956 Evolution of drainage systems and slopes in badlands at Perth Amboy, New Jersey; Geol. Soc. Am. Bull. 67(5) 597-646.

Shehata M and Mizunaga H 2018 Flash flood risk assessment for Kyushu Island, Japan; Environ. Earth Sci. 77(3) 76.

Singh N and Singh K K 2017 Geomorphological analysis and prioritization of sub-watersheds using Snyder's synthetic unit hydrograph method; App. Water Sci. 7(1) 275-283.

Singh P, Thakur J and Singh U C 2013 Morphometric analysis of Morar River Basin, Madhya Pradesh, India, using remote sensing and GIS techniques; Environ. Earth Sci. 68 1967-1977.

Strahler A 1957 Quantitative analysis of watershed geomorphology; Trans. Am. Geophys. Union 38 913-920.

Strahler A 1964 Quantitative geomorphology of drainage basins and channel networks; In: Handbook of applied hydrology (ed.) Chow V, McGraw Hill, New York, pp. 439-476.

Tehrany M S, Pradhan B and Jebur M N 2014 Flood susceptibility mapping using a novel ensemble weightsof-evidence and support vector machine models in GIS; $J$. Hydrol. 512 332-343.

Youssef A M, Pradhan B, Gaber A F D, Buchroithner M F 2009 Geomorphological hazard analysis along the Egyptian Red Sea coast between Safaga and Quseir. Nat. Hazards Earth Syst. Sci. 9(3) 751-766.

Youssef A M, Pradhan B and Hassan A M 2011 Flash flood risk estimation along the St. Katherine road, Southern Sinai, Egypt using GIS based morphometry and satellite imagery; Environ. Earth Sci. 62 611-623.

Youssef A M, Pradhan B and Sefry S A 2016 Flash flood susceptibility assessment in Jeddah city (Kingdom of Saudi Arabia) using bivariate and multivariate statistical models; Environ. Earth Sci. 75(1) 12.

Zhao G, Xue H and Ling F 2010 Assessment of ASTER GDEM performance by comparing with SRTM and ICESat/GLAS data in Central China; In: 2010 18th international conference on geoinformatics, IEEE, pp. 1-5. 